
ВИВЧЕННЯ ТЕМИ «ВІДДІЛЕННЯ ЛІКАРНІ» НА ЗАНЯТТЯХ З УКРАЇНСЬКОЇ
МОВИ ЯК ІНОЗЕМНОЇ В ЗАКЛАДАХ ВИЩОЇ МЕДИЧНОЇ ОСВІТИ (СТАТТЯ 2)

\title{
STUDY OF THE THEME "HOSPITAL DEPARTMENTS" AT THE LESSONS IN UKRAINIAN AS A FOREIGN LANGUAGE IN ESTABLISHMENTS OF HIGHER MEDICAL EDUCATION (ARTICLE 2)
}

У статті запропоновано систему завдань
до вивчення теми «Відділення лікарні» (друге
заняття) на заняттях з української мови як
іноземної в закладах вищої медичної освіти.
Закцентовано, що опанування курсу «Укра-
їнська мова як іноземна» не лише передбачає
формування базових комунікативних умінь
і навичок, необхідних для успішної адапта-
ції в чужомовному соціокультурному про-
сторі, а й відіграє важливу роль у здобутті
обраної спеціальності, оскільки практичне
оволодіння мовою дає змогу бути актив-
ним учасником фрахово зорієнтованого ком-
петентного спілкування. Підкреслено, що
актуальним в сучасній лінгводидактиці є
розроблення навчально-методичного забез-
печення, яке сприяло б фрормуванню комуні-
кативної компетенції, готовності до забез-
печення базових комунікативних потреб у
навчально-профресійній сфрері. Комплекс вправ, представлений у цій статmі, $\epsilon$ логічним продовженням попередньої роботи. Він спрямований на закріплення граматичного й лексичного матеріалу, вивченого на першому занятті, присвяченому темі «Відділення лікарні» (лексика на позначення відділень лікарні, систем організму, частин тіла людини, хвороб, травм і їхніх симптомів; уживання дієслів у теперішньому часі, узгодження слів у реченні). Система завдань розроблена відповідно до програмних вимог, ґрунтується на принципах науковості, доступності, систематичності й послідовності, зв'язку теорії з практикою. Запропонований навчально-методичний матеріал спрямований на реалізацію комунікативного підходу до вивчення іноземних мов, має на меті розширення словникового запасу медичної тематики, розвиток умінь оперувати вивченою лексикою, будувати висловлювання відповідно до граматичних норм української мови, розвиток навичок усного й письмового мовлення та апробований авторами публікації на заняттях з української мови як іноземної. Авторська методична розробка орієнтована на студентів, що володіють мовою на початковому рівні.

Ключові слова: українська мова як іноземна методична розробка, профресійне спілку- вання, навчально-методичні матеріали, комунікативна компетенція.

The article proposes a system of tasks for studying the topic "Hospital Departments" (second lesson) in classes in the Ukrainian language as a foreign one in institutions of higher medical education. It is emphasized that mastering the course "Ukrainian as a foreign language" not only involves the formation of basic communication skills necessary for successful adaptation in a foreign socio-cultural space, but also plays an important role in obtaining the chosen specialty, as practical language acquisition allows competent communication. It is emphasized that relevant in modern linguodidactics is the development of educational and methodological support, which would contribute to the formation of communicative competence, readiness to provide basic communicative needs in the educational and professional sphere.

The set of exercises presented in this article is a logical continuation of previous work and aims to consolidate the grammatical and lexical material studied in the first lesson on the topic "Hospital Departments" (vocabulary to denote hospital departments, body systems, human body parts, diseases, injuries and their symptoms, the use of verbs in the present tense, the coordination of words in a sentence). The system of tasks is developed in accordance with the program requirements, is based on the principles of scientificity, accessibility, systematicity and consistency, the connection of theory with practice. The proposed educational and methodical material is aimed at implementing a communicative approach to learning foreign languages, aims to expand the vocabulary of medical topics, the development of skills to use the learned vocabulary, to build utterances in accordance with grammatical norms of the Ukrainian language, oral and written skills and is tested by authors in Ukrainian language as a foreign one classes. The methodological instruction proposed in the article is aimed at students who speaks the language at the elementary level.

Key words: Ukrainian language as foreign one, methodical instruction, professional communication, educational and methodical materials, communicative competence. медичного університету імені І.Я. Горбачевського

Постановка проблеми в загальному вигляді. У закладах вищої освіти України навчаються багато іноземних студентів, які, окрім іншого, повинні опанувати й курс «Українська мова як іноземна», зорієнтований на фрормування як базових комунікативних умінь, необхідних для спілкування в побуті, навчанні тощо, так і на підготовку до спілкування в українськомовному професійному середовищі. Курс має важливе значення для адаптації в чужому соціокультурному просторі та $€$ необхідним для результативного навчання, оскільки практичне оволодіння мовою допомагає бути активним учасником фрахово зорієнтованого компетентного спілкування. Розроблення навчально-методичного забезпечення дисципліни «Українська мова як іноземна» є актуальним у сучасній лінгводидактиці.

Аналіз останніх досліджень і публікацій. Проблема методики викладання курсу «Українська мова як іноземна» $€$ предметом наукового зацікавлення багатьох учених, зокрема Н.С. Голод, Н.В. Кобзей, I.М. Кочан, С.М. Луцак, К.Л. Стефанишин, М.П. Тишковець та інших. Навчально-методичні матеріали, спрямовані на формування вмінь і навичок фрахового спілкування майбутніх медичних працівників, 
запропоновані в працях І.Я. Заліпської, В.І. Зевако, Т.П. Мельник, О.І. Новіцької, Л.П. Шеремети та інших $[1 ; 2 ; 3 ; 4 ; 5]$.

Виділення не вирішених раніше частин загальної проблеми. Актуальність запропонованої праці обумовлена тим, що фрормування українськомовної комунікативної компетенції іноземних студентів у ссрері професійного спілкування фахівців медичних спеціальностей у лінгводидактиці ще недостатньо розроблене.

Мета статті. Мета статті - розробити комплекс завдань до теми «Відділення лікарні» для другого практичного заняття. Запропонований дидактичний матеріал апробований на заняттях авторами публікації та зорієнтований на фрормування вмінь і навичок професійної комунікації майбутніх лікарів.

Виклад основного матеріалу. Тему «Відділення лікарні» студенти вивчають на двох практичних заняттях. У попередній публікації ми запропонували методичну розробку для викладача до першого заняття $з$ цієї теми [2]. Комплекс вправ, представле- ний у статті, є логічним продовженням попередньої роботи, спрямований на закріплення вивченого граматичного й лексичного матеріалу, розширення фрахового словникового запасу, розвиток умінь i навичок будувати власне висловлювання.

Завдання 1. Відповідайте на запитання.

1. Який лікар лікує захворювання сечовидільної системи? 2. Який лікар лікує захворювання вуха, горла й носа? 3. Який лікар лікує захворювання органів зору? 4. Який лікар лікує захворювання серцево-судинної системи? 5. Який лікар лікує захворювання органів травлення? 6. Який лікар лікує захворювання органів дихання? 7. Який лікар лікує захворювання ендокринної системи? 8. Який лікар видаляє апендикс при апендициті? 9. Який лікар забезпечує анестезію? 10. Який лікар лікує захворювання опорно-рухового апарату? 11. Які $€$ органи травлення? 12. Які $€$ органи дихання? 13. Які частини тіла належать до опорнорухового апарату? 14. Які органи належать до серцево-судинної системи?

Завдання 2. Поєднайте слова з колонок А і Б. Утворіть речення за зразком.

Зразок: В ортопедо-травматологічному відділенні лікують вивих, перелом.

\begin{tabular}{|l|l|}
\hline А & $\begin{array}{l}\text { Б } \\
\text { Хідділення лікарні }\end{array}$ \\
\hline 1. Ендокринологічне відділення & А. Гастрит, виразка, гепатит С, панкреатит, холецистит \\
\hline 2. Офтальмологічне відділення & Б. Бронхіальна астма, пневмонія \\
\hline 3.Оториноларингологічне відділення & В. Міокардит, гіпертонічна хвороба, ішемічна хвороба серця, розлад кровообігу \\
\hline 4. Гастроентерологічне відділення & Г. Сечокам'яна хвороба, цистит, патологія сечового міхура \\
\hline 5. Кардіологічне відділення & Ґ. Цукровий діабет, патологія щитоподібної залози \\
\hline 6. Урологічне відділення & Д. Короткозорість, далекозорість, катаракта, астигматизм \\
\hline 7. Пульмонологічне відділення & Е. Аденоїдит, синусит, отит, тонзиліт. \\
\hline
\end{tabular}

Завдання 3. Прочитайте та запам'ятайте назви хвороб і їхні симптоми.

\begin{tabular}{|c|c|c|}
\hline № & Хвороба, травма & Симптоми \\
\hline 1. & Апендицит & Гострий біль справа внизу живота, набряк живота, нудота, блювота \\
\hline 2. & Перелом ноги & Сильний біль, десрормація кінцівки, кінцівка набрякає \\
\hline 3. & Синусит & $\begin{array}{l}\text { Гнійні виділення з носа жовтого або зеленого кольору, головний біль, втрата нюху, } \\
\text { підвищення температури }\end{array}$ \\
\hline 4. & Інфраркт міокарда & $\begin{array}{l}\text { Інтенсивний біль у серці, що поширюється в руку, спину або шию, блідість, } \\
\text { задишка, слабкість }\end{array}$ \\
\hline 5. & Пневмонія & Кашель, підвищена температура, біль у грудях, хворого морозить, задишка \\
\hline 6. & Пульпіт & Сильний зубний біль, біль посилюється від гарячої їжі, біль поширюється на всю щелепу \\
\hline 7. & Бронхіальна астма & Свистяче дихання, нестача повітря, задишка, важкість у грудях \\
\hline 8. & Цукровий діабет & Хронічна втома, суха шкіра, спрага, повільне загоєння ран \\
\hline 9. & Грип & $\begin{array}{l}\text { Підвищена температура, головний біль, біль у м'язах і суглобах, слабкість, } \\
\text { потовиділення, біль у горлі }\end{array}$ \\
\hline 10. & Отит & Біль у вусі, знижується слух, підвищена температура, гнійні виділення з вуха \\
\hline 11. & Астигматизм & Біль в очах, почервоніння очей, знижується зір \\
\hline 12. & Алергія & Набряк губ, язика, шиї, обличчя, нежить, сльозотеча, кашель, висип, свербіж \\
\hline 13. & Гіпертонічна хвороба & Головний біль, запаморочення, шум у вухах, біль у серці \\
\hline 14. & Отруєння & Нудота, блювота, діарея, хворого морозить, підвищена температура \\
\hline
\end{tabular}

Завдання 4. Доповніть речення. Використовуйте слова з завдання 3.

(Пневмонія) Це Мартин. Він сильно ... . У нього підвищена ... , і його ... . Він відчуває ... . Крім того, у нього ... . Це симптоми ... . Хворих на пневмонію лікують у ... відділенні. Потрібно, щоб його також оглянув пульмонолог.

(Апендицит) Це Анна. У неї ... . Крім того, у неї ... і ... . Це симптоми ... . Апендицит лікують у ... відділенні. Потрібно, щоб ії оглянув ... . 
(Перелом) Це Катя. У неї сильно болить ... . Кінцівка здеорормована і ... . Це симптоми .... Травми опорно-рухового апарату лікують у ... відділенні. Потрібно, щоб її оглянув .... .

(Синусит) Це Олексій. У нього ... 3 носа. У нього сильний ... і підвищена ... . Це симптоми ... . Захворювання носа лікують у ... відділенні. Потрібно, щоб його оглянув .... .

(Інфраркт міокарда) Це Максим. У нього ... . Він блідий, у нього ... та ... . Це симптоми ... . Захворювання серцево-судинної системи лікують у ... відділенні. Потрібно, щоб його оглянув .... .

(Бронхіальна астма) Це Софрія. У неї ... дихання. Вона відчуває ... . Також їі турбують ... та ... . Це симптоми ... . Захворювання органів дихання лікують у ... відділенні. Потрібно, щоб її оглянув .... .

(Отит) Це Єва. У неї болить ... . Слух знизився. Також у неї ... та ... . Це симптоми ... . Хвороби вуха лікують в ... відділенні. Потрібно, щоб ії оглянув .... .

Завдання 5. Розгляньте малюнки та дайте відповіді на запитання. (Викладач показує студентам малюнки, на яких зображені шпатель, шприц, термометр, щипці, тонометр, хірургічні ножиці, стетоскоп, скальпель.)

1. Що зображено на малюнку?

2. Хто використовує цей предмет?

3. Для чого його застосовують?

Використовуйте слова з довідки.

Зразок: На малюнку зображений шприц. Найчастіше його використовує медсестра. Шприц використовують для ін'єкцій.

Довідка: ін'єкції, проведення хірургічних операцій, видалення зубів, вислуховування шумів внутрішніх органів (серця, легень), вимірювання температури, зняття швів, вимірювання артеріального тиску, огляд горла.

Завдання 6. Перепишіть речення. Поставте дієслова в теперішній час

1. Хірург оперував хворого. 2. В Арсена була температура. Він пив багато рідини. 3. Кардіолог рекомендував хворому багато відпочивати. 4. Лікарі радили їсти здорову їжу. 5. Медсестра робила хворому укол. 6. Пульмонолог оглядав пацієнта, вислуховував легені. 7. Я хворіла на гастрит. 8. Ви вивчали анатомію? 9. У мене вчора боліла голова. 10. Ми вчилися надавати першу медичну допомогу. 11. Лікар виписав рецепт. 12. Арсен працював стоматологом. Він видаляв зуби, лікував пульпіт. 13. Ми бачили Настю в аптеці. Вона купувала ліки та термометр. 14. Олена погано себе почувала. Її турбував сильний кашель і нежить.

Завдання 7. Запишіть речення, вставляючи потрібне слово.

1. Учора Денис впав з велосипеда і ... ногу. Зараз він у лікарні, йому ... гіпс. 2. У Сосрії ... на котів. Вона чхає весь день. 3 Хірург в ... кімнаті оперує хворого. 4. У хворого висока температура, його .... . 5. ... - це посиніле місце на тілі, що виникає внаслідок удару. 6. ... - часте, важке дихання, нестача повітря. 7. В Ореста сильно болить вухо. Йому потрібно негайно звернутися до ... . 8. У кардіологічному відділенні лікують захворювання ... системи. 9. Хворим з високою температурою потрібно ... багато рідини. 10. Якщо болить голова, потрібно прийняти .... . 11. У хворого симптоми анемії. Потрібно зробити аналіз ... . 12. Стоматолог-терапевт лікує пульпіт, ставить ... . 13. Судинний хірург оперує ... . 14. Лікар бере ..., щоб виміряти артеріальний тиск.

Завдання 8. Поєднайте словосполучення з колонок А і Б. Утворіть речення за зразком.

Зразок: У хворого алергія, тому йому потрібно прийняти антигістамінний препарат.

Якщо у хворого алергія, то йому потрібно прийняти антигістамінний препарат.

\begin{tabular}{|l|l|}
\hline А & Б \\
\hline 1. Серцевий напад & А. Викликати швидку допомогу \\
\hline 2. Знепритомніти & Б. Прийняти аспірин \\
\hline 3. Сильний кашель & В. Зробити фрлюорограсрію \\
\hline 4. Болить голова & Г. Накласти гіпс \\
\hline 5. Зламати руку & Ґ. Прикласти холодне або лід \\
\hline 6. Висока температура & Д. Забезпечити доступ свіжого повітря \\
\hline 7. Синець & Е. Пити багато рідини \\
\hline
\end{tabular}

Висновки. Формування умінь і навичок фрахового спілкування $€$ одним із важливих фракторів успішного навчання. Лексичний і граматичний матеріал, на якому побудовані вправи, підібраний з урахуванням комунікативних і пізнавальних потреб студентів. Система завдань, запропонована у статті, має на меті розширення словникового запасу, розвиток умінь граматично правильно використовувати його у власному мовленні, будувати власне висловлювання та розроблена з урахуванням комунікативного підходу, ґрунтується на принципах науковості, доступності, систематичності й послідовності, зв'язку теорії з практикою.

Перспективу подальших пошуків у напрямі дослідження вбачаємо в розробленні навчально-методичних матеріалів для занять медичної тематики. 
БІБЛІОГРАФІЧНИЙ СПИСОК:

1. Зевако В.І. Система вправ і завдань для формування професійно орієнтованого спілкування майбутніх лікарів (на матеріалі теми «Медицина. Медичні спеціальності. Медичний персонал» з української мови як іноземної). Інноваційна педагогіка. 2019. Вип. 13. С. 90-94.

2. Мисик О.А. Вивчення теми «Відділення лікарні» на заняттях з української мови як іноземної у закладах вищої медичної освіти. Інноваційна педагогіка. 2020. Вип. 21. Т. 2. С. 24-27.

3. Українська мова як іноземна для англомовних студентів-медиків : підручник 3 електрон. аудіодо- датком : у 2 кн. Кн. 1. Соціокультурна комунікація / С.М. Луцак та ін. ; за ред. С.М. Луцак. Київ : Медицина, 2019. 504 с.

4. Українська мова як іноземна для англомовних студентів-медиків : підручник з електрон. аудіододатком : у 2 кн. Кн. 2. Основи професійного мовлення / С.М. Луцак та ін. ; за ред. С.М. Луцак. Київ : Медицина, 2019. 456 с.

5. Українська мова як іноземна для студентів медичних спеціальностей : навчальний посібник / І.І. Гаврищак та ін. ; за ред. М.П. Тишковець. Тернопіль : ТНМУ, 2019. 312 с. 